九州大学学術情報リポジトリ

Kyushu University Institutional Repository

\title{
Co-Culture with Amniotic Membrane Stem Cells for Oocyte Maturation and Early Embryonic Development in Bovine
}

Han, Ki l-Woo

Department of Animal Science and Biotechnology, College of Agriculture and Life Science, Chungnam National University

Chun, Ju Lan

Department of Animal Science and Biotechnology, College of Agriculture and Life Science, Chungnam National University

Lee, Ji Hey

Department of Animal Science and Biotechnology, College of Agriculture and Life Science, Chungnam National University

Kim, Keun-Jung

Department of Animal Science and Biotechnology, College of Agriculture and Life Science, Chungnam National University

他

https://doi.org/10.5109/1526400

出版情報：九州大学大学院農学研究院紀要. 60 (2)，pp.393-398，2015-09-18. Faculty of Agriculture, Kyushu University

バージョン :

権利関係 : 


\title{
Co-Culture with Amniotic Membrane Stem Cells for Oocyte Maturation and Early Embryonic Development in Bovine
}

\section{Kil-Woo HAN ${ }^{* * *}$, Ju Lan CHUN ${ }^{1 * *}$, Ji Hey LEE ${ }^{1}$, Keun-Jung KIM ${ }^{1}$, Kyung-Bon LEE ${ }^{2}$, Taksfumi GOTOH, Chang Hee $\mathrm{DO}^{3 *}$ and Min Kyu $\mathrm{KIM}^{1 *}$}

\author{
Kuju Agricultural Research Center, Faculty of Agriculture, \\ Kyushu University, Kuju, Oita, 878-0201, Japan \\ (Received May 18, 2015 and accepted May 19, 2015)
}

\begin{abstract}
To improve early embryonic development, many strategies have been studied in various species including bovine. The co-culture of embryos with somatic cells has been known to improve embryo quality during in vitro culture and pregnancy rates compared with conventional culture systems. The co-culture of embryos with oviductal cells which have been used for blastocyst expansion appears to shorten the time needed for synthesis of hCG, early embryo development, and hatching blastocysts. The aim of this study is to investigate whether the co-culture system with amniotic membrane stem cells (bAMS) improves bovine embryonic development competence.

In order to investigate the influence of bAMS on early embryo development, bAMS originated from fetal bovine amniotic membranes were used as the feeder layer during in vitro maturation. The rates of matured oocytes, cleavage division, and blastocysts formation were increased $(p<0.05)$ after co-culture with the bAMS compared to the control group. Moreover the rates of oocyte maturation and embryo development were significantly higher with using bAMS below 5 passages. In addition, the GSH level and the total cell number of blastocysts were significantly higher in co-culture group than in those of control group. Apoptotic cells were found more in the control group, and the expression of anti-apoptosis related genes such as Mcl-1 and Bcl-2 were increased after co-culture with bAMS.

In conclusion, the present study demonstrated that co-culture with bAMS cells enhances oocyte maturation and embryo developmental competence by increasing GSH level and expression of anti-apoptotic genes with reducing apoptotic cells in bovine embryos. We also found that it is more suitable to use bAMS below 5 passages.
\end{abstract}

Key words: amniotic stem cells, bovine embryo, co-culture, Hanwoo

\section{INTRODUCTION}

Co-culture system has been used in in vitro culture (IVC) of embryos. It has been reported that using a coculture system with various somatic cells improves embryo quality and pregnancy rates (Dominguez et al., 2010). The co-culture system has been also known to reduce the time of embryo development and hatching blastocyst with increasing the synthesis of hCG (Menzo et al., 1990; Fanchin et al., 2001). The cells used as the feeder layer release antioxidants such as hypotaurine which is one of the natural free radical scavengers in the embryo environment (Cassuto et al., 2003; Guerin et al., 1995). Many researches have been conducted to improve the co-culture conditions by using various types of cells. However, how co-culture system provides beneficial environment to embryos during IVC is not definitely known.

Several studies have been trying and developing suc-

Department of Animal Science and Biotechnology, College of Agriculture and Life Science, Chungnam National University, 220 Gung-dong, Yuseong-gu, Daejeon 305-764, Korea

${ }^{2}$ Department of Biology Education, College of Education, Chonnam National University, Gwangju 500-757, Korea

${ }^{3}$ Department of Animal Biosystem Science, College of Agriculture and Life Science, Chungnam National University, 220 Gung-dong, Yuseong-gu, Daejeon 305-764, Korea

* Corresponding author: Min Kyu Kim, DVM, Ph.D. and Chang Hee Do, Ph.D. (E-mail: kminkyu@cnu.ac.kr, ivando@cnu.ac.kr)

** Kil Woo HAN and Ju Lan Chun have contributed equally to this work cessful techniques to obtain high quality of oocytes. For example, ultrasound-guided ovum pick up (OPU) technology is a method that allows obtaining a large number of oocytes from live donors with high genetic advantages (Kruip et al., 1994). OPU is possible to be conducted every 3 5 days intervals without hormone treatment and able to use same live donor animals continuously. The technique has been known to be useful to produce numerous oocytes compared to the multiple ovulation/embryo transfer (MOET) method (Pontes et al., 2011). However, OPU system is still in need to be optimized (Goovaertsa et al., 2010). OPU is able to collect approximately only $5 \sim 10$ oocytes per animal at a time which requires to culture oocytes in a small number of a group (Petyim et al., 2003; Machado et al., 2006). It has been accepted that in vitro culture system in a large number improves the maturation of oocytes by secreting several growth factors (Lim et al., 1996; O'Neill et al., 1997). Moreover oocytes collected by OPU include different degrees of quality. A poor quality of cumulus-oocyte-complex (COC) reduces not only the number of oocytes to be cultured at a time but also the subsequent embryo development compared to the oocytes with multi-layers and compact COC (Ferry et al., 1994). Therefore it would be important to develop advanced IVM system for small number of immature oocytes including a poor quality of COC that allow obtaining more matured oocytes and reducing the number of oocytes needed.

Oocyte quality affects on embryo development 
(Hardy et al., 2000), and it has been noticeably recognized in bovine oocytes among those of any other species (Sirard et al., 2006). Oocytes obtain the ability to resume meiosis during in vitro maturation (Richard et al., 1996) prior to be fertilized, cleaved and develop (Ware et al., 1989, Dinnyes et al., 2000) that achieves pregnancy (Peterson et al., 2003). With that, the present study aims that co-culture with bAMS provides a beneficial environment for the maturation of bovine oocytes including further embryo development. In order to confirm the influence of co-culture with bAMS, we investigated the level of GSH, apoptosis, and apoptosis related gene expression.

\section{MATERIALS AND METHODS}

\section{Chemicals and Animals}

All chemicals and reagents were purchased from Sigma-Aldrich Chemical Co. (St. Louis. MO. USA) unless otherwise stated. Three Hanwoo were used as oocyte donors for OPU. All animals are healthy, non-pregnant, non-lactating, and cycling. The average age of Hanwoos was around 5 years and they were weighing $400 \pm 35 \mathrm{~kg}$. The animals belonged to Chungnam livestock Research Institute. All animal studies were performed in accordance with recommendations described in "The Guide for the Care and Use of Laboratory Animals" published by Institutional Animal Care and Use Committee of Chungnam livestock Research Institute.

\section{Oocytes Collection by OPU}

Follicular aspiration was performed as described by the previous report (Seneda et al., 2008). Briefly, each follicle of $\geq 2 \mathrm{~mm}$ in diameter was aspirated using ultrasound scanner (Mylab30Vet GOLD, Italy). A $7.5 \mathrm{MHz}$ convex array transducer was fitted into the intravaginal device and guided by a stainless steel. Follicular puncture was performed by using a disposable 19-gauge $\times$ $60 \mathrm{~mm}$ needle (JEIL TECH CO, Korea) connected to a $50 \mathrm{ml}$ conical tube (BD Falcon, USA) via a silicon tube. Aspiration was performed by using a vacuum pump (Gast, USA) with a negative pressure of 10 to $12 \mathrm{ml}$ of water/ min. The aspirated sediments were immediately filtered through a con filter. Oocytes were collected through the needle, transferred into $0.25 \mathrm{ml}$ sterile straw and immediately transported to the laboratory by a portable $36^{\circ} \mathrm{C}$ incubator.

COCs were classified into four grades based on the presence and morphology of cumulus cell layers: (A) Complete and compact $>1 \sim 3$ COC layer, (B) 1 3 compact layer, (C) partial layer and (D) denuded oocytes and expanded/loosened cumulus cells.

\section{Isolation and In Vitro Culture of bAMS}

Bovine amniotic membranes were obtained from a local slaughterhouse. The samples were transferred to the laboratory in a short time. The collected membranes were washed with phosphate-buffered saline (PBS; Gibco, USA) containing $0.1 \%$ penicillin-streptomycin (500 U/ml penicillin-5 mg/ml streptomycin; Gibco, USA) and minced in washing medium supplemented with $5 \%$ fetal bovine serum (FBS) (Gibco, USA). After minced, the pellets were washed with washing medium and centrifuged at 2,000 rpm for $5 \mathrm{~min}$ twice. The bovine amniotic membrane cells were grown in low-glucose Dulbecco modified Eagle medium (L-DMEM) (Sigma-Alorich, USA) supplemented with 10\% FBS, 0.1\% penicillin/streptomycin, 5 ng basic fibroblast growth factor (bFGF) (SigmaAlorich, USA) and $10 \mathrm{ng}$ epidermal growth factor (EGF) (Sigma-Alorich, USA) at $39^{\circ} \mathrm{C}$ with $5 \% \mathrm{CO}_{2}$ and $5 \% \mathrm{O}_{2}$.

\section{Oocytes Collection from Slaughterhouse-Derived Ovaries}

Ovaries were collected from animals shortly after slaughtering at a local slaughterhouse and transported to the laboratory within $3 \mathrm{~h}$ in physiological saline containing penicillin/streptomycin at 30 to $35^{\circ} \mathrm{C}$. Ovaries were then washed three times in fresh warmed saline. The contents of antral follicles of 2 to $8 \mathrm{~mm}$ in diameter were aspirated using an 18-gauge needle attached to a $10 \mathrm{ml}$ disposable syringe. Follicular fluid with oocytes was collected in $15 \mathrm{ml}$ centrifuge tubes and allowed to settle for 10 to $15 \mathrm{~min}$. The sedimentation was washed two times in HEPES-buffered Tissue Culture Medium 199 supplemented with $0.5 \%(\mathrm{w} / \mathrm{v})$ bovine serum albumin (BSA fatty acid free, Gibco.), $2 \mathrm{mM}$ sodium bicarbonate and 10 mM HEPES (Sigma Co.). COCs surrounded by cumulus cells and homogeneous cytoplasm were selected for further experiments.

\section{In Vitro Maturation, In Vitro Fertilization and In Vitro Culture}

The bAMS were cultured in 4-well dish in L-DMEM containing $10 \%$ FBS and $0.1 \%$ penicillin/streptomycin. After $24 \mathrm{~h}$, the culture medium of bAMS was changed to oocyte maturation medium (TCM199 Supplemented with $10 \%$ FBS).

The COCs of co-culture group were cultured in the 4-well dish which contains pre-cultured feeder layer in $500 \mu \mathrm{l}$ TCM199-culture medium supplemented with 10\% FBS, 1 mg/ml FSH (folltropin-V ${ }^{\circledast}$, Bioniche Co., Belleville, Canada), $1 \mu \mathrm{g} / \mathrm{ml}$ estradiol-17 $\beta, 0.2 \mathrm{mM}$ sodium pyruvate, and $1 \mu \mathrm{g} / \mathrm{ml}$ epidermal growth factor. The COCs of control group were maturated without feeder layers in vitro in incubator at $38.5^{\circ} \mathrm{C}$ in $5 \% \mathrm{CO}_{2}$ with saturated humidity for 22 24 h.

Fertilization was accomplished by frozen/thawed semen of fertile Hanwoo. Straws were thawed for 1 min in a water bath at $36^{\circ} \mathrm{C}$. Sperms were washed in $4 \mathrm{ml}$ of Tyrode's albumin-lactate pyruvate (TALP)-capacitation medium followed by centrifugation at $800 \times \mathrm{g}$ for $6 \mathrm{~min}$ twice, and was capacitated in TALP medium supplemented with heparin $(20 \mu \mathrm{g} / \mathrm{ml})$. Sperm concentration was adjusted to $1 \times 10^{7} \mathrm{sperm} / \mathrm{ml}$ in TALP-IVF medium. After maturation, COCs were washed three times in TCM-washing medium and inseminated in TALP-IVF medium containing sperms in $50 \mu \mathrm{l}$ droplets covered by mineral oil. The droplets (10 COCs/droplet) were incubated under the same gas atmosphere as for IVM.

After 18 20 h, sperms and cumulus cells around pre- 
sumptive zygotes were removed by gentle pipetting in a TCM-washing medium. After then, the presumptive zygotes were transferred to $50 \mu \mathrm{l}$ droplets of culture medium consisting of modified synthetic oviduct fluid medium with essential and non-essential amino acids and bovine serum albumin (BSA) in modular chamber with a gas atmosphere of $5 \% \mathrm{CO}_{2}$ for 7 days.

\section{Measurement of GSH}

The level of GSH was measured by using 4-chloromethyl-6.8-difluoro-7-hydroxycoumarin (CellTracker Blue; CMF2HC; Invitrogen Corporation). Briefly, matured oocytes were washed in DPBS supplement with $0.10 \mathrm{~g} / \mathrm{L}$ $\mathrm{CaCl}_{2}$ and $0.10 \mathrm{~g} / \mathrm{L} \mathrm{MgCl}_{2} \cdot 6 \mathrm{H}_{2} \mathrm{O}$. After washing, oocytes were transferred into bovine zygote medium mSOF containing $100 \mu \mathrm{M} \mathrm{TBHP}$ at $39^{\circ} \mathrm{C}$ in $5 \% \mathrm{CO}_{2}$ for $60-90 \mathrm{~min}$. After 60-90 min of incubation, oocytes were transferred into DPBS containing $25 \mu \mathrm{M}$ carboxy-H2DCFDA and $25 \mu \mathrm{M}$ Cell Tracker Blue, and incubated for $30 \mathrm{~min}$ at $39^{\circ} \mathrm{C}$ in $5 \% \mathrm{CO}_{2}$ protected from light. After incubating for 30 min, oocytes were washed in DPBS. The fluorescent emissions from the oocytes were recorded using the camera attached to a fluorescence microscope with UV filters $(370 \mathrm{~nm}$ for $\mathrm{GSH})$. The recorded fluorescent images were analyzed by Image $J$ software (Version 1.46r; National Institutes of Health, Bethesda, MD, USA) and normalized to those of control oocytes.

\section{TUNEL Assay}

TUNEL assay was performed to assess the presence of apoptotic cells (In Situ Cell death Detection Kit, TMR red) in blastocysts. At day 7 blastocysts were washed 3 times for 5 min in PBS-PVA (containing 0.1\% PVA). Embryos were fixed in 4\% paraformaldehyde in PBS-PVA for $1 \mathrm{~h}$ and permeabilized in PBS-PVA with 1.0\% Trition $\mathrm{X}-100$ for $30 \mathrm{~min}$ at room temperature. The embryos were washed in PBS-PVA for 3 times and incubated in TUNEL reaction medium (Enzyme solution: Label solutions $=1: 9$ ) for $1 \mathrm{~h}$ at $37^{\circ} \mathrm{C}$ in dark. After the reaction completed, the embryos were washed and stained with hoechest 33342 and mounted in mounting medium (Vectashield, Vector Laboratories, Inc, CA) at room temperature in dark. The number of apoptotic nuclei and fragments were subsequently subjected to confocal laser scanning microscopy.

\section{RNA Isolation and RT-PCR}

mRNA was isolated from triplicate pools of 10 blastocysts using oligo (dT) 25-attached magnet beads (Dynalbead, Invitrogen) according to the manufacturer's instructions. Briefly, embryos in lysis buffer were mixed with $40 \mu \mathrm{l}$ of binding buffer (20 mM Tris-HCl, pH 7.5, $1 \mathrm{M} \mathrm{LiCl}, 2 \mathrm{mM}$ EDTA, $\mathrm{pH}$ 8.0), and incubated at $65^{\circ} \mathrm{C}$ for 5 min to facilitate the lysis of the embryo and release of RNA. Oligo (dT) magnetic beads were washed three times with washing buffer (10 mM Tris-HCl, pH 7.5, 0.15 LiCl, 1 mM EDTA, pH 8.0). Finally, mRNA samples were eluted in $10 \mu \mathrm{l}$ of double-distilled diethylpyrocarbonate $\mathrm{C}$-treated water and reverse transcribed using oligo (dT) primer and iScript reverse transcriptase (BIO-RAD,
US).

Synthesized cDNA was amplified by PCR using specific primers for anti- apoptosis genes (Mcl-1 and Bcl-w). PCR reaction was consisted of 5 min denaturation at $94^{\circ} \mathrm{C}$, followed by 35 cycles at $94^{\circ} \mathrm{C}$ for $30 \mathrm{sec}, 62^{\circ} \mathrm{C}$ for $30 \mathrm{sec}$ and $72^{\circ} \mathrm{C}$ for $30 \mathrm{sec}$. A final extension for 5 min was performed at $72^{\circ} \mathrm{C}$. Amplified target genes by RT-PCR were confirmed by DNA sequencing, and RT-PCR results were evaluated by Image $\mathrm{J}$ software.

\section{Statistical Analysis}

All data were analyzed using one way ANOVA software program (SPSS statistics Inc. ver 18.0.0). A $\mathrm{p}$-value $<0.05$ was considered to be statistically significant.

\section{RESULTS}

\section{The grades of OPU-derived oocytes}

The grades of recovered oocytes from aspirated follicles by OPU are shown in Table. 1. Oocytes with complete and compact $>3$ layers of cumulus cells (A grade) and oocytes with 1 3 layers of cumulus cells (B grade) were consisted of $57.9 \%$ of total recovered oocytes from aspirated follicles by OPU. $16.3 \%$ of oocytes have no cumulus cell layer that is considered as poor quality cumulus-oocyte complexes.

Table 1. Evaluation of oocytes recovered by OPU

\begin{tabular}{ccccc}
\hline \multirow{2}{*}{$\begin{array}{c}\text { Total no. of } \\
\text { recovered } \\
\text { oocytes }\end{array}$} & A & B & C & D \\
\cline { 2 - 5 } & $62(24.6 \%)$ & $84(33.3 \%)$ & $57(22.6 \%)$ & $49(16.3 \%)$ \\
\hline
\end{tabular}

(A) Complete and compact 1 3> multilayer, (B) 1 3 compact layer, (C) partial layer, (D) no cumulus cell or expanded cumulus cells. ( $\mathrm{N}$ of Hanwoo = 3 )

\section{The effect of co-culture with bAMS on oocyte mat- uration and early embryonic development}

Feeder layers of bAMS were used during IVM for immature oocytes. In comparison with the immature oocytes cultured without bAMS feeder layers during IVM there were increased matured oocytes significantly $(75.6 \%)$. In addition, the rates of embryo cleavage and blastocyst formation were also increased (63.8\%, 29.2\%) $(\mathrm{p}<0.05)$ (Fig. 1.a)

\section{The effect of bAMS senescence on oocyte matura- tion and early embryonic development in co-cul- ture system}

The effect of the bAMS senescence was investigated in co-culture system based on the rates of oocyte maturation and embryo development. When bAMS were over passage 6 there was no significant difference in the rates of oocyte maturation and embryo development $(p<0.05)$ compared to the control group (Fig 1.b). However, the rates of oocyte maturation and blastocyst formation in the group of co-culture with below 5 passages of bAMS 


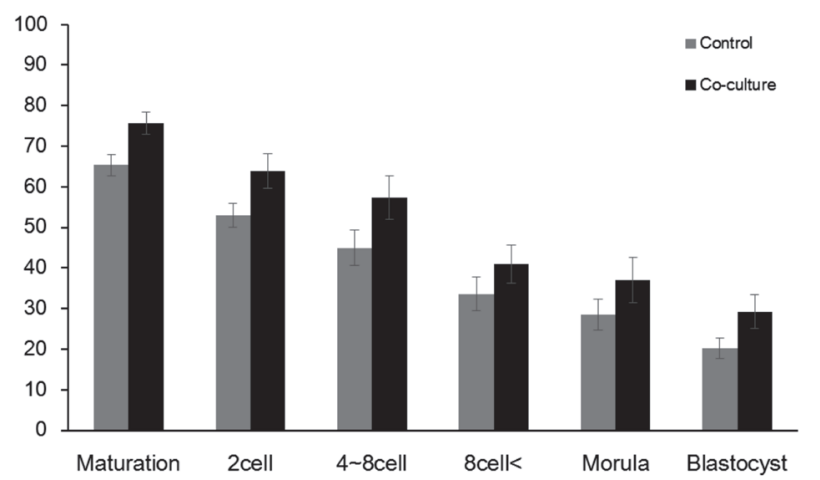

Fig. 1. a. Rates of oocyte maturation and embryo development after co-culture with bAMS.

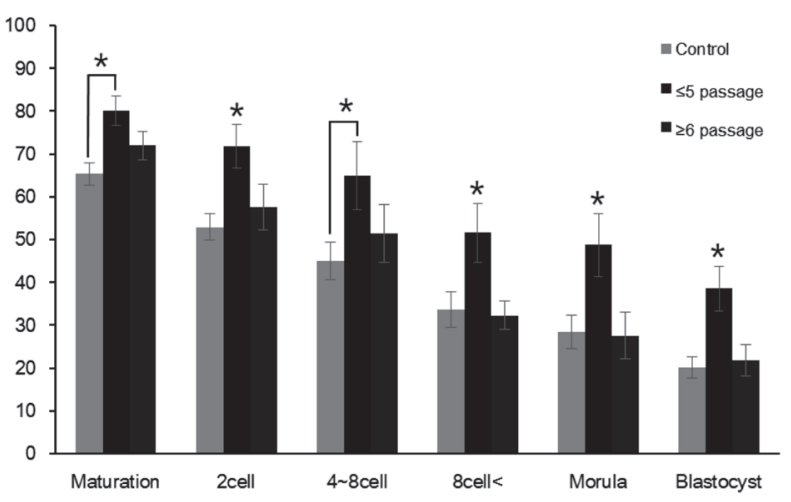

Fig. 1. b. The effect of bAMS senescence on the rates of oocyte maturation and embryo development. $* P<0.05$.

were significantly higher than the control group $(p<0.05)$ (Fig 1.b).

\section{Measurement of GSH in matured oocytes}

Matured oocytes were selected based on the presence of first polar body and the level of oocyte maturation and anti-oxidant activity was measured by GSH expression. GSH was detected by using Blue CMF2HC (Fig. 2). The relative expression level of GSH was significantly higher in the oocytes from the co-culture group than those of the control group.

\section{Apoptosis}

To investigate the effect of co-culture on cell death in blastocysts TUNEL staining was performed with blastocysts at 7 day from both control and co-culture groups. Total cell numbers of the blastocysts in co-culture group were significantly higher (105.0 \pm 2.92$)$ than control group (82.2 \pm 8.13 ). Apoptotic cells of blastocyst in the control group (3.2 \pm 0.66$)$ were higher than co-culture group (1.4 \pm 0.51$)$. However, there was no significant difference (Table 2).

\section{Expression of anti-apoptotic genes}

To determine whether the bAMS feeder layers affect on apoposis in bovine embryos development, the expression of anti-apoptotic genes was detected by RT-PCR

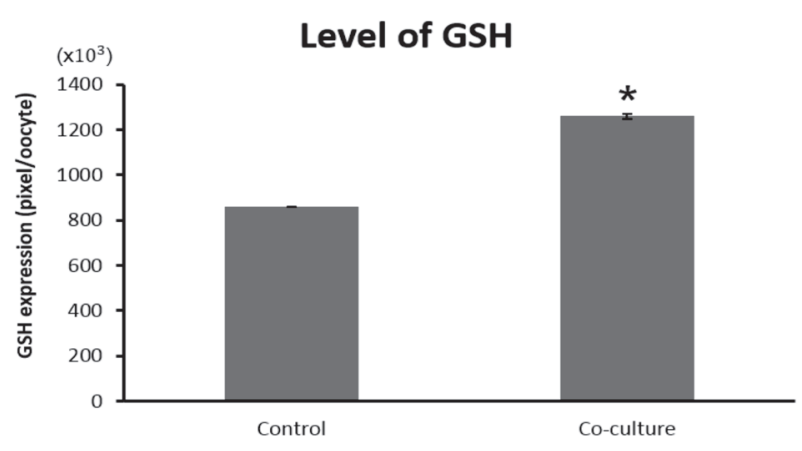

Fig. 2. The expression level of GSH in in vitro matured bovine oocytes by co-culture with bAMS. $* P<0.05$
Table 2. The number of apoptotic cells in blastocysts after 7 days in vitro culture

\begin{tabular}{cccc}
\hline & Blastocyst & $\begin{array}{c}\text { Total cells } \\
(\text { mean+SEM) }\end{array}$ & $\begin{array}{c}\text { Apoptotic cells } \\
\text { (mean+SEM) }\end{array}$ \\
\hline Control & 5 & $\begin{array}{c}411 \\
(82.2 \pm 13)^{\mathrm{a}}\end{array}$ & $\begin{array}{c}16 \\
(3.2 \pm 0.66)\end{array}$ \\
\hline Co-culture & 5 & 525 & 7 \\
\hline a-b & $(105 \pm 2.92)^{\mathrm{b}}$ & $(1.4 \pm 0.51)$ \\
\hline
\end{tabular}

${ }^{a-b}$ Values with different superscripts are significantly different $(P$ $<0.05)$.

\begin{tabular}{|c|c|c|c|}
\hline & Genes & Control & Co-culture \\
\hline \multirow{2}{*}{ Anti-apoptosis } & Mcl-1 & & \\
\hline & $\mathrm{Bcl}-\mathrm{w}$ & & \\
\hline GAP & & & \\
\hline
\end{tabular}

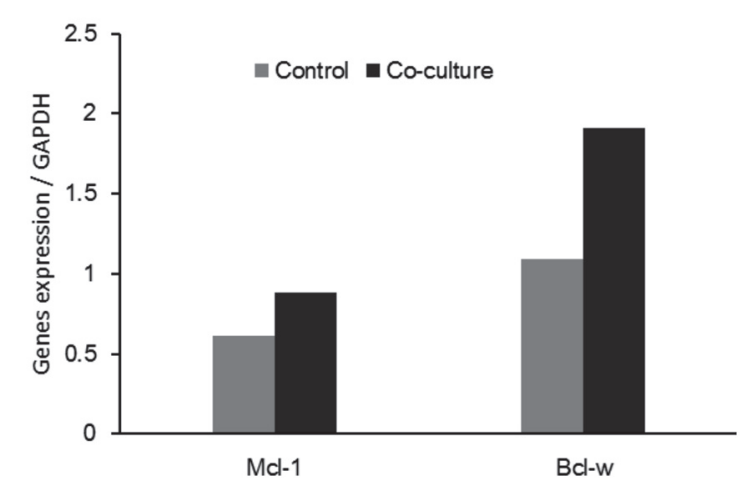

Fig. 3. Expressions of anti-apoptosis related genes in blastocysts were confirmed by RT-PCR. RT-PCR results were analyzed by using Image J software

(Fig. 3). The results indicated that the expression of anti-apoptotic genes such as Mcl-1, Bcl-w in bovine embryos was increased (Fig. 3), and apoptotic genes were not expressed both control and co-culture groups (Data not shown). 


\section{DISCUSSION}

The amniotic sac contains fetus and amniotic fluid that provides essential environment for developing fetus. The amnion is a thin transparent membrane surrounding fetus which is comprised of three major layers: an epithelial monolayer, a thick basement membrane, and an avascular stroma (Niknejad et al., 2008). The amniotic membrane is basically to protect the embryo and secrets cytokines that maintain the crucial environment to develop fetus. It has been shown that native amnion contains higher levels of EGF, KGF, HGF, bFGF, TNF- $\alpha$, NGF, BDNF and activin (Koizumi et al., 2000, Uchida et al., 2000). The basement membrane of the amnion involves collagen, fibronectin, laminin and other proteoglycans that have important roles in cell adhesion and growth (Niknejad et al., 2008). The epithelium of amniotic innermost layer produces prostaglandins and prostaglandin E2 ( $\mathrm{PGE}_{2}$ ) (Okazaki et al., 1981), also expresses prostaglandin biosynthesis enzymes (Bryant-Greenwood et al., 1987; Toda et al., 2007). $\mathrm{PGE}_{2}$ may induce the indirect stimulation of cumulus expansion (Eppig, 1981). Expansion of cumulus has important roles for maturation, fertilization, and embryonic development (Downs et al., 1988; Hizaki et al., 1999). $\mathrm{PGE}_{2}$ has an ability of stimulating cell cycle progress during oocyte maturation and early embryo development. (Nuttinck et al., 2011). Recently, the amnion has been also applied clinically, and stem cells derived from amniotic membrane have been studied (Parolini et al., 2008 ; Yu et al., 2009).

In the present study, co-culture with bAMS induced significantly increased oocyte maturation and embryo developmental competence. It is probably due to the several growth factors and cytoprotective cytokines secreted from bAMS. In addition co-culture of bAMS below 5 passage improved oocyte maturation and embryo development competence more than those of bAMS cells over 6 passage. Therefore the early passage of bAMS promotes oocyte maturation and embryo development, and the later passage of bAMS would attenuate the benefit of the co-culture with bAMS.

In this study, the oocytes matured on the bAMS feeder layers expressed higher GSH level, and blastocysts after co-culture with bAMS had significantly the increased total cell number with decreased apoptosis. Moreover, anti-apoptotic gene expressions were increased in blastocysts after co-culture with bAMS. GSH maintains the redox state and protects the detrimental effect of oxidative damage (Lafleur et al., 1994 ; Pastore et al., 2003). Embryo quality and developmental competence were improved when GSH synthesis was increased during in vitro maturation (de Matos et al., 2000). Apoptosis is an active physiological process which triggers chromatin condensation, reducing cell volume, resulting in fragments and removal of unnecessary, damaged and risky individual cells (Schwartzman and Cidlowski 1993). In addition, the correlation of the embryo development and apoptosis in arrested bovine embryos was reported (Antunes et al., 2010). Apoptosis is controlled by the activity of proand anti-apoptotic genes, during pre-implantation devel- opment (Bergeron et al., 1998).

In conclusion, the present study demonstrated that co-culture system with bAMS during in vitro maturation improved oocyte maturation and embryo development by increasing GSH level, increasing anti-apoptotic gene expression and reducing DNA fragmentation in embryos. Therefore co-culture with bAMS would be an optimal in vitro culture system to improve the efficiency of oocyte maturation and embryo development that allow obtaining high quality of oocytes.

\section{ACKNOWLEDGMENTS}

This study was supported by grant from the NextGeneration BioGreen 21 program (Grant No. PJ011359) funded by the Rural Development Administration, Republic of Korea.

\section{REFERENCES}

Antunes, G., A. Chaveiro, P. Santos, A. Marques, H. S. Jin and F. Moreira da Silva 2010 Influence of apoptosis in bovine embryo's development. Reprod. Domest. Anim., 45(1): 26-32

Bergeron, L., G. I. Perez, G. Macdonald, L. Shi, Y. Sun, A. Jurisicova, S. Varmuza, K. E. Latham, J. A. Flaws, J. C. Salter, H. Hara, M. A. Moskowitz, E. Li, A. Greenberg, J. L. Tilly and J. Yuan 1998 Defects in regulation of apoptosis in caspase-2-deficient mice. Genes Dev., 12(9): 1304-1314

Bryant-Greenwood, G. D., M. C. Rees and A. C. Turnbull 1987 Immunohistochemical localization of relaxin, prolactin and prostaglandin synthase in human amnion, chorion and decidua. J. Endocrinol., 114(3): 491-496

Cassuto, G., M. Chavrier and Y. Menezo 2003 Culture conditions and not prolonged culture time are responsible for monozygotic twinning in human in vitro fertilization. Fertil. Steril., $\mathbf{8 0}(2): 462-463$

de Matos, D. G. and C. C. Furnus 2000 The importance of having high glutathione (GSH) level after bovine in vitro maturation on embryo development effect of beta-mercaptoethanol, cysteine and cystine. Theriogenology, 53(3): 761-771

Dinnyes, A., Y. Dai, S. Jiang and X. Yang 2000 High developmental rates of vitrified bovine oocytes following parthenogenetic activation, in vitro fertilization, and somatic cell nuclear transfer. Biol. Reprod., 63(2): 513-518

Dominguez, F., B. Gadea, A. Mercader, F. J. Esteban, A. Pellicer and C. Simon 2010 Embryologic outcome and secretome profile of implanted blastocysts obtained after coculture in human endometrial epithelial cells versus the sequential system. Fertil. Steril., 93(3): 774-782 e771

Downs, S. M., S. A. Daniel and J. J. Eppig 1988 Induction of maturation in cumulus cell-enclosed mouse oocytes by folliclestimulating hormone and epidermal growth factor: evidence for a positive stimulus of somatic cell origin. J. Exp. Zool., 245(1): 86-96

Eppig, J. J. 1981 Prostaglandin E2 stimulates cumulus expansion and hyaluronic acid synthesis by cumuli oophori isolated from mice. Biol. Reprod., 25(1): 191-195

Fanchin, R., J. M. Ayoubi, C. Righini, F. Olivennes, L. M. Schonauer and R. Frydman 2001 Uterine contractility decreases at the time of blastocyst transfers. Hum. Reprod., 16(6): 1115-1119

Ferry, L., P. Mermillod, A. Massip and F. Dessy 1994 Bovine embryos cultured in serum-poor oviduct-conditioned medium need cooperation to reach the blastocyst stage. Theriogenology, 42(3): 445-453

Goovaerts, I. G., J. L. Leroy, E. P. Jorssen and P. E. Bols 2010 Noninvasive bovine oocyte quality assessment: possibilities of a single oocyte culture. Theriogenology, 74(9): 1509-1520

Guerin, P. and Y. Menezo 1995 Hypotaurine and taurine in gam- 
ete and embryo environments: de novo synthesis via the cysteine sulfinic acid pathway in oviduct cells. Zygote, 3(4): 333-343

Hardy, K., C. S. Wright, S. Franks and R. M. Winston 2000 In vitro maturation of oocytes. Br. Med. Bull., 56(3): 588-602

Hizaki, H., E. Segi, Y. Sugimoto, M. Hirose, T. Saji, F. Ushikubi, T. Matsuoka, Y. Noda, T. Tanaka, N. Yoshida, S. Narumiya and A. Ichikawa 1999 Abortive expansion of the cumulus and impaired fertility in mice lacking the prostaglandin E receptor subtype EP(2). Proc. Natl. Acad. Sci. U S A, 96(18): 1050110506

Koizumi, N. J., T. J. Inatomi, C. J. Sotozono, N. J. Fullwood, A. J. Quantock and S. Kinoshita 2000 Growth factor mRNA and protein in preserved human amniotic membrane. Curr. Eye Res., 20(3): 173-177

Kruip, T. A., R. Boni, Y. A. Wurth, M. W. Roelofsen and M. C. Pieterse 1994 Potential use of ovum pick-up for embryo production and breeding in cattle. Theriogenology, 42(4): 675-684

Lafleur, M. V., J. J. Hoorweg, H. Joenje, E. J. Westmijze and J. Retel 1994 The ambivalent role of glutathione in the protection of DNA against singlet oxygen. Free Radic. Res., 21(1): 9-17

Lim, J. M. and W. Hansel 1996 Roles of growth factors in the development of bovine embryos fertilized in vitro and cultured singly in a defined medium. Reprod. Fertil. Dev., 8(8): 1199-1205

Machado, S. A., H. D. Reichenbach, M. Weppert, E. Wolf and P. B. Goncalves 2006 The variability of ovum pick-up response and in vitro embryo production from monozygotic twin cows. Theriogenology, $\mathbf{6 5}(3)$ : 573-583

Menezo, Y. J., J. F. Guerin and J. C. Czyba 1990 Improvement of human early embryo development in vitro by coculture on monolayers of Vero cells. Biol. Reprod., 42(2): 301-306

Niknejad, H., H. Peirovi, M. Jorjani, A. Ahmadiani, J. Ghanavi and A. M. Seifalian 2008 Properties of the amniotic membrane for potential use in tissue engineering. Eur. Cell Mater., 15: 88-99

Nuttinck, F., L. Gall, S. Ruffini, L. Laffont, L. Clement, P. Reinaud, P. Adenot, B. Grimard, G. Charpigny and B. Marquant-Le Guienne 2011 PTGS2-related PGE2 affects oocyte MAPK phosphorylation and meiosis progression in cattle: late effects on early embryonic development. Biol. Reprod., 84(6): 12481257

O'Neill, C. 1997 Evidence for the requirement of autocrine growth factors for development of mouse preimplantation embryos in vitro. Biol. Reprod., 56(1): 229-237

Okazaki, T., M. L. Casey, J. R. Okita, P. C. MacDonald and J. M. Johnston 1981 Initiation of human parturition. XII. Biosynthesis and metabolism of prostaglandins in human fetal membranes and uterine decidua. Am. J. Obstet. Gynecol. 139(4): 373-381

Parolini, O., F. Alviano, G. P. Bagnara, G. Bilic, H. J. Buhring, M. Evangelista, S. Hennerbichler, B. Liu, M. Magatti, N. Mao, T. Miki, F. Marongiu, H. Nakajima, T. Nikaido, C. B. PortmannLanz, V. Sankar, M. Soncini, G. Stadler, D. Surbek, T. A. Takahashi, H. Redl, N. Sakuragawa, S. Wolbank, S. Zeisberger, A. Zisch and S. C. Strom 2008 Concise review: isolation and characterization of cells from human term placenta: outcome of the first international Workshop on Placenta Derived Stem Cells. Stem Cells, 26(2): 300-311

Pastore, A., G. Federici, E. Bertini and F. Piemonte 2003 Analysis of glutathione: implication in redox and detoxification. Clin. Chim. Acta, 333(1): 19-39

Peterson, A. J. and R. S. Lee 2003 Improving successful pregnancies after embryo transfer. Theriogenology, 59(2): 687-697

Petyim, S., R. Bage, T. Hallap, A. S. Bergqvist, H. RodriguezMartinez and B. Larsson 2003 Two different schemes of twice-weekly ovum pick-up in dairy heifers: effect on oocyte recovery and ovarian function. Theriogenology, 60(1): 175188

Pontes, J. H., F. A. Melo Sterza, A. C. Basso, C. R. Ferreira, B. V. Sanches, K. C. Rubin and M. M. Seneda 2011 Ovum pick up, in vitro embryo production, and pregnancy rates from a large-scale commercial program using Nelore cattle (Bos indicus) donors. Theriogenology, 75(9): 1640-1646

Richard, F. J. and M. A. Sirard 1996 Effects of follicular cells on oocyte maturation. II: Theca cell inhibition of bovine oocyte maturation in vitro. Biol. Reprod., 54(1): 22-28

Schwartzman, R. A. and J. A. Cidlowski 1993 Apoptosis: the biochemistry and molecular biology of programmed cell death. Endocr. Rev., 14(2): 133-151

Sirard, M. A., F. Richard, P. Blondin and C. Robert 2006 Contribution of the oocyte to embryo quality. Theriogenology, 65(1): 126-136

Toda, A., M. Okabe, T. Yoshida and T. Nikaido 2007 The potential of amniotic membrane/amnion-derived cells for regeneration of various tissues. J. Pharmacol. Sci., 105(3): 215-228

Uchida, S., Y. Inanaga, M. Kobayashi, S. Hurukawa, M. Araie and N. Sakuragawa 2000 Neurotrophic function of conditioned medium from human amniotic epithelial cells. J. Neurosci. Res., 62(4): 585-590

Ware, C. B., F. L. Barnes, M. Maiki-Laurila and N. L. First 1989 Age dependence of bovine oocyte activation. Gamete Res., 22(3): 265-275

Yu, S. J., M. Soncini, Y. Kaneko, D. C. Hess, O. Parolini and C. V. Borlongan 2009 Amnion: a potent graft source for cell therapy in stroke. Cell Transplant., 18(2): 111-118 